\title{
Sanfilippo Syndrome, Type D: A Spectrophotometric Assay with Prenatal Diagnostic Potential
}

\author{
ROD W. NOWAKOWSKI, JERRY N. THOMPSON, AND KENNETH B. TAYLOR
}

\begin{abstract}
Laboratory of Medical Genetics [R. W. N., J. N. T.J, Department of Optometry [R. W. N.], and Department of Biochemistry [J. N. T., K. B. T.], The Medical Center, University of Alabama at Birmingham,
\end{abstract}

Birmingham, Alabama 35294

\begin{abstract}
Sanfilippo syndrome, type D (MPS IIID), is characterized by moderate physical abnormalities, progressive mental deterioration, and deficient activity of $\mathrm{N}$ acetylglucosamine 6-sulfate sulfatase, a lysosomal hydrolase involved in the degradation of heparin, keratan sulfate, and heparan sulfate. To date, demonstration of the enzyme deficiency typically relies on a radiolabeled trisaccharide substrate derived from heparan sulfate. In our study, we have developed a spectrophotometric assay for the determination of $\mathrm{N}$-acetylglucosamine 6-sulfate sulfatase activity using the monosaccharide, $\mathrm{N}$-acetylglucosamine 6-sulfate, as substrate. The reaction mixture was incubated for $6 \mathrm{~h}$ at $37^{\circ} \mathrm{C}$ and, after Dowex chromatography, released $\mathrm{N}$-acetylglucosamine was measured by a modification of the method of Reissig. Assay conditions were optimized for cultured skin fibroblasts and primary cultures of amniotic fluid cells. The $\mathrm{pH}$ optimum for each was 5.5. The assay was linear for $24 \mathrm{~h}$ and up to 0.1 absorbance units. Activities of the three known MPS IIID skin fibroblast cell lines were more than $4 \mathrm{SD}$ below the skin fibroblast control mean and more than 5 SD below the control mean for amniotic fluid cells. An enzyme deficiency in cultured amniotic fluid cells of the same magnitude as the skin fibroblasts of the known patients would be detectable and, therefore, prenatal diagnosis by this method is feasible. (Pediatr Res 26:462-466, 1989)
\end{abstract}

\section{Abbreviations}

AFC, amniotic fluid cells

GlcNAc, N-acetylglucosamine

GlcNAc(6S), N-acetylglucosamine 6-sulfate

GlcNAc 6-sulfatase, N-acetylglucosamine 6-sulfate sulfatase

MPS, mucopolysaccharidosis

MPS IIID, Sanfilippo syndrome, type D

DMAB, $p$-dimethylaminobenzaldehyde

NMR, nuclear magnetic resonance

Received February 13, 1989; accepted June 29, 1989. Correspondence and reprint requests Rod W. Nowakowski, University of Alabama at Birmingham/The Medical Center, School of Optometry, University Station, Birmingham, AL 35294.

Supported in part by BRSG S07 RR05807 awarded by the Biomedical Research Support Grant Program, Division of Research Resources, National Institutes of Health, the Department of Health and Human Services (Maternal and Child Health Project 905), and a Service Grant (C426) from the March of Dimes Birth Defects Foundation.
The Sanfilippo syndrome is a lysosomal storage disease and has been designated as MPS III. The four types of the Sanfilippo syndrome (A, B, C, and D) have a clinical presentation characterized by physical changes similar to, but milder than, other mucopolysaccharidoses, severe mental deterioration that is progressive, and increased urinary excretion of partially degraded heparan sulfate (1). Although the four types cannot be distinguished on clinical grounds alone (2) each is distinct in having deficient activity of a different lysosomal enzyme involved in the metabolism of heparan sulfate.

MPS IIID was first recognized when Kresse et al. (3) reported two patients with clinical manifestations of the Sanfilippo syndrome who had heparan sulfaturia and who were unable to release sulfate from GlcNAc(6S) residues in oligosaccharides derived from heparan sulfate. MPS IIID appears to be rare and, to date, there are only seven reported patients (4-7). The diagnosis was confirmed by enzyme assay for six of these patients and selected clinical and biochemical findings for them are summarized in Table 1. The diagnosis of MPS IIID is confirmed by demonstrating a deficiency of GlcNAc 6-sulfatase, EC 3.1.6.14) in cultured fibroblasts or leukocytes. The substrate used typically is the tritium labeled trisaccharide $O-(\alpha-\mathrm{D}-6$-sulfo-2acetamido-2-deoxyglucosyl)-( $1 \rightarrow 4)$ - $O$-uronosyl-( $1 \rightarrow 4)-2,5$-anhydro-D-[1- $\left.{ }^{3} \mathrm{H}\right]$ mannitol (8) made from heparan sulfate through a lengthy sequence of steps (9). The use of the radiolabeled monosaccharide $\left[1-{ }^{14} \mathrm{C}\right] \mathrm{GlcNAc}(6 \mathrm{~S})$ for diagnosis of MPS IIID has been reported but has not found general usage perhaps because the reported rate of desulfation was greater for the trisaccharide and because free sulfate, an effective inhibitor of enzyme activity, was found to be difficult to remove after the preparation of GlcNAc(6S) by direct sulfation of GlcNAc with chlorosulfonic acid $(10)$.

GlcNAc 6-sulfatase has been purified from human urine (9) and human liver (11). Robertson et al. (12) localized the gene for this enzyme to chromosome region $12 \mathrm{q} 14$.

Our study was undertaken to develop an effective diagnostic assay for MPS IIID using an inexpensive and easily prepared monosaccharide substrate with a spectrophotometric procedure for detection of free GlcNAc, a reaction product, after desulfation by GlcNAc 6-sulfatase. By eliminating the use of radiolabeled materials and the laborious preparation of the tritium labeled trisaccharide substrate, the assay would be within the capabilities of many additional laboratories, potentially making the diagnosis more readily available. GlcNAc 6-sulfatase has not been studied in primary cultures of amniotic fluid cells and therefore, additional aspects of this study were to determine selected characteristics of the enzyme in this important tissue source and to determine the potential applicability of the spectrophotometric assay to prenatal diagnosis. Preliminary results of this study have been reported (13). 
Table 1. Selected clinical and biochemical findings reported in patients with enzymatically confirmed MPS IIID

\begin{tabular}{|c|c|c|c|c|c|c|}
\hline & \multicolumn{6}{|c|}{ Patient (Reference) } \\
\hline & $1(4)$ & $2(4)$ & $3(5)$ & $4(5)$ & $5(6)$ & $6(7)$ \\
\hline Origin* & Italian & Italian & Italian & Italian & Italian & French-Irish \\
\hline Consanguinity & No & Yes & No† & No† & No & Not reported \\
\hline Sex & $\mathrm{F}$ & $\mathrm{F}$ & M & $\mathrm{F}$ & $\mathrm{M}$ & $\mathrm{F}$ \\
\hline Age at report & $4 \% / 12$ & $106 / 12$ & $98 / 12$ & $54 / 12$ & 9 & 5 \\
\hline $\begin{array}{l}\text { Age at first sign of neurological in- } \\
\text { volvement }\end{array}$ & $36 / 12$ & 3 & 8 & 2 & Not reported & 3 \\
\hline Ocular involvement & No & $\begin{array}{l}\text { Pigmentary } \\
\text { retinal } \\
\text { degener- } \\
\text { ation }\end{array}$ & No & No & No & Optic atrophy \\
\hline $\begin{array}{l}\text { Enzyme activity (\% of normal } \\
\text { mean) }\end{array}$ & 6.1 & 6.1 & 4.6 & 4.4 & $0 \ddagger$ & $<3.4$ \\
\hline Mental retardation & Mild & Severe & Mild & Severe & Mild & Severe \\
\hline $\begin{array}{l}\text { Coarse facies/hirsutism/mild dysos- } \\
\text { tosis multiplex and limitation of } \\
\text { elbow extension }\end{array}$ & Yes & Yes & Yes & Yes & Yes & Yes \\
\hline Hepatomegaly & Yes & Yes & Yes & No & No & Yes \\
\hline
\end{tabular}

* One patient in literature, not described clinically, is of East Indian origin.

$\dagger$ Reportedly nonconsanguineous but from same small town.

$\ddagger$ Affected brother with similar features at age $13 / 12$ but enzyme deficiency not confirmed.

\section{MATERIALS AND METHODS}

Chemical reagents. Reagents were purchased as follows: Sephadex G-10, Pharmacia Fine Chemicals (Uppsala, Sweden); Nacetylglucosamine, $\mathrm{N}$-acetylglucosamine 6-sulfate, 3,3-dimethylglutaric acid, $p$-dimethylaminobenzaldehyde, and bicinchoninic protein assay kit, Sigma Chemical Company (St. Louis, MO); Dowex AG 1-X8, 200-400 mesh, chloride form, Bio-Rad (Richmond, CA); potassium tetraborate, Fisher Scientific (Fair Lawn, $\mathrm{NJ}$ ); chloroform and chlorosulfonic acid, Aldrich Chemical Company (Milwaukee, WI); pyridine, Pierce Chemical Co. (Rockford, IL). All other chemicals were of reagent grade.

Method of Reissig. Reissig et al. (14) described a spectrophotometric assay that is both sensitive and highly specific for $\mathrm{N}$ acetylated hexosamines. A modification of this method was used for the detection of GlcNAc(6S) during its preparation and for the detection of released GlcNAc in the enzyme assay described below. Two reagents were used: potassium tetraborate $\left(\mathrm{K}_{2} \mathrm{~B}_{4} \mathrm{O}_{7}\right.$. $4 \mathrm{H}_{2} \mathrm{O}$ ), $0.6 \mathrm{M}$ with respect to $\mathrm{B}_{4} \mathrm{O}_{7}$, adjusted to $\mathrm{pH} 9.5$ with concentrated $\mathrm{HCl}$ and $1 \mathrm{~g}$ of DMAB dissolved in $10 \mathrm{~mL}$ of glacial acetic acid containing $12.5 \%$ (vol/vol) of $10 \mathrm{~N} \mathrm{HCl}$. The stock DMAB reagent was diluted immediately before use with 9 vol of glacial acetic acid to 1 vol of the stock solution. A $500-\mu \mathrm{L}$ sample was heated in boiling water for $3 \mathrm{~min}$ after the addition of $100 \mu \mathrm{L}$ of the potassium tetraborate reagent. The sample was then cooled for $3 \mathrm{~min}$ in a room temperature water bath followed by the addition of $3 \mathrm{~mL}$ of the diluted $\mathrm{DMAB}$ reagent and incubation in a $37^{\circ} \mathrm{C}$ water bath for $20 \mathrm{~min}$. It was again cooled for $3 \mathrm{~min}$ in a room temperature water bath and the absorbance was measured in $1.0 \mathrm{~cm}$ quartz cuvettes at $585 \mathrm{~nm}$ with a Bausch \& Lomb Spectronic 2000 spectrophotometer (Fisher). For larger or smaller samples the reagents were scaled up or down proportionately. The assay was optimized for detection of GlcNAc with respect to the $\mathrm{pH}$ of the potassium tetraborate reagent, after which the following assay characteristics were determined for GlcNAc: absorption spectrum, change in absorbance with respect to time, and change in absorbance with respect to concentration.

Substrate preparation. GlcNAc(6S) was prepared by direct sulfation of GlcNAc with chlorosulfonic acid by modification of the methods of Lloyd (15) and Ishihara et al. (16). A total of $1 \mathrm{~g}$ of GlcNAc was dissolved in $33 \mathrm{~mL}$ of pyridine. This solution was cooled to $0^{\circ} \mathrm{C}$ followed by the dropwise addition of $680 \mu \mathrm{L}$ of chlorosulfonic acid in $3.3 \mathrm{~mL}$ of chloroform with constant stirring. The mixture was stirred continuously for $30 \mathrm{~min}$ at $0^{\circ} \mathrm{C}$ and then for $1 \mathrm{~h}$ at room temperature, after which it was neutralized with $5 \mathrm{M} \mathrm{NaOH}$ (approximately $5.5 \mathrm{~mL}$ ). After neutralization, an oily layer separated to the bottom. This layer was extracted with a glass pipette and diluted in water. Initially, free $\mathrm{SO}_{4}^{-2}$ was precipitated with $\mathrm{Ba}(\mathrm{OH})_{2}$ and $\mathrm{Ba}^{+2}$ was then removed by precipitation with dry ice or $\mathrm{CO}_{2}$ gas after which the supernatant was diluted to reduce conductivity and applied to a column $(1.5 \times 10 \mathrm{~cm})$ of Dowex AG1-X8, 200-400 mesh, chloride form. The precipitation steps were subsequently eliminated by desalting over a column $(2.0 \times 125 \mathrm{~cm})$ of Sephadex G-10 eluted with $5 \%$ ethanol in water. The elution of $\mathrm{SO}_{4}{ }^{-2}$ and $\mathrm{Cl}^{-}$were followed by $\mathrm{Ba}(\mathrm{OH})_{2}$ and $\mathrm{AgNO}_{3}$ precipitation, respectively. The elution of $\mathrm{N}$-acetylhexosamine was followed by the modified Reissig method. The peak fractions having a positive reaction were pooled, concentrated by rotary evaporation in a Büchi model RE-111A rotary evaporator (Fisher), diluted to reduce conductivity and applied to a column $(1.5 \times 10 \mathrm{~cm})$ of Dowex AG1-X8, 200-400 mesh, chloride form, washed with $100 \mathrm{~mL} \mathrm{H} \mathrm{H}_{2} \mathrm{O}$ and eluted stepwise with $100 \mathrm{~mL}$ each of, 0.015 $\mathrm{M}, 0.2 \mathrm{M}$, and $0.5 \mathrm{M} \mathrm{NaCl}$. Fractions eluted with $0.2 \mathrm{M} \mathrm{NaCl}$ were combined, rotary evaporated, and desalted over a column $(1.0 \times 180 \mathrm{~cm})$ of Sephadex G-10 eluted with $5 \%$ ethanol in water. Several preparations of GlcNAc(6S) were combined, desalted a second time over a column $(2.0 \times 125 \mathrm{~cm})$ of Sephadex G-10, characterized for content, and used as substrate for assay of GlcNAc 6-sulfatase activity. During the course of study, GlcNAc(6S) became available as a commercial preparation; however, it was available only intermittently and varied in physical appearance. The commercial preparation and the GlcNAc(6S) made by direct sulfation were compared as described below.

Substrate characterization. Thin-layer chromatography was performed with glass or polyester backed silica gel plates (Sigma). The two solvent systems used were $n$-butanol:acetic acid: $\mathrm{H}_{2} \mathrm{O}$ $(50: 25: 25)$ and $n$-propanol: $\mathrm{H}_{2} \mathrm{O}(88: 12)$. Plates were developed for $15 \mathrm{~h}$ and dried, after which each lane was marked in $1-\mathrm{cm}$ sections, each of which was then scraped into $500 \mu \mathrm{L}$ of $\mathrm{H}_{2} \mathrm{O}$ in a $13 \times 100 \mathrm{~mm}$ glass tube and assayed by the modified method of Reissig. Molecular size exclusion gel chromatography was performed with a column $(1.0 \times 180 \mathrm{~cm})$ of Sephadex G-10 eluted with $5 \%$ ethanol. Anion exchange chromatography was accomplished with $1 \mathrm{~mL}$ of Dowex AG 1-X8, 200-400 mesh, chloride form, in a disposable polyethylene filter column (Fisher) washed with $5 \mathrm{~mL}$ of $\mathrm{H}_{2} \mathrm{O}$ and eluted stepwise with $5 \mathrm{~mL}$ each of $0.01,0.02,0.05,0.1,0.2,0.5$ and $1.0 \mathrm{M} \mathrm{NaCl}$. Samples for 
NMR spectroscopy were prepared as $5 \mathrm{mM}$ solutions in $\mathrm{D}_{2} \mathrm{O}$ (99.8\%) and analyses were performed on a Bruker WH-400 spectrometer.

Cell culture. Five skin fibroblast cell lines, recovered from liquid nitrogen storage, and an additional five cell lines from normal individuals were used as controls along with cell line GM 302A (NIGMS Human Genetic Mutant Cell Repository, Camden, NJ). Cell lines from three patients with Sanfilippo syndrome, type D, were available for study: GM 5093 (NIGMS Human Genetic Mutant Cell Repository, Camden, NJ), WG 1004 (The Repository for Mutant Human Cell Strains, Montreal, Quebec), and MGE-SFD (graciously provided by Dr. E. Kolodny, Waltham, MA). Other sulfatase-deficient cell lines were obtained from the NIGMS Human Genetic Mutant Cell Repository, Camden, New Jersey as follows: GM 0615 (Hunter syndrome), GM 2849 (Maroteaux-Lamy syndrome), GM 1881 (Sanfilippo A Syndrome), GM 4681 (multiple sulfatase deficiency), and GM 3245 (multiple sulfatase deficiency). One additional sulfatase deficient cell line was recovered from liquid nitrogen (Laboratory of Medical Genetics, University of Alabama at Birmingham): MGE-MSD (multiple sulfatase deficiency).

Cell cultures were maintained at $37^{\circ} \mathrm{C}$ with $5 \% \mathrm{CO}_{2}$ in closed flasks (Corning Glass Works, Corning, NY) with McCoy's 5a medium (GIBCO, Grand Island, NY) supplemented with $10 \%$ fetal bovine serum (GIBCO), $1 \%$ antibiotic combination (penicillin $10000 \mathrm{U} / \mathrm{mL}$, streptomycin $10000 \mu \mathrm{g} / \mathrm{mL}$ ) and gentamicin sulfate (Elkins-Sinn, Inc., Cherry Hill, NJ) $40 \mu \mathrm{g} / \mathrm{mL}$. Cells were subcultured at confluency after trypsinization. For enzyme studies, cells were harvested 10-14 d after subculture in $0.15 \mathrm{M}$ $\mathrm{NaCl}$ with disposable plastic scrapers (Costar, Cambridge, MA), cooled in an ice bath, sonicated five times for $5 \mathrm{~s}$ each time, centrifuged at $9000 \times g$ for $30 \mathrm{~min}$ at $5^{\circ} \mathrm{C}$ and the supernatant retained for enzyme assay. Proteins were measured with the bicinchoninic protein assay kit using BSA as a standard.

Primary amniotic fluid cell cultures with normal karyotypes (Laboratory of Medical Genetics, University of Alabama at Birmingham) were maintained in $25 \mathrm{~cm}^{2}$ flasks in the same manner described above for skin fibroblasts and were harvested after 3-4 wk in culture, without having been subcultured. They were prepared for enzyme assay in the same manner as the skin fibroblasts.

Enzyme assay. The incubation mixture consisted of $100 \mu \mathrm{L}$ of $100 \mathrm{mM} \mathrm{3,3-dimethylglutarate,} \mathrm{pH} 5.5,50 \mu \mathrm{L}$ of $31 \mathrm{mM}$ GlcNAc(6S) containing $100 \mu \mathrm{g}$ of sodium azide $\left(\mathrm{NaN}_{3}\right)$, and 50 $\mu \mathrm{L}$ of fibroblast sonicate (30-60 $\mu \mathrm{g}$ protein) in $0.15 \mathrm{M} \mathrm{NaCl}$ at $37^{\circ} \mathrm{C}$. After $6 \mathrm{~h}$, the reaction mixture was diluted with $300 \mu \mathrm{L}$ $\mathrm{H}_{2} \mathrm{O}$ and added to $1 \mathrm{~mL}$ of Dowex AG $1-\mathrm{X} 8,200-400$ mesh, chloride form. The void volume and three $500 \mu \mathrm{L}$ fractions, eluted with $1.5 \mathrm{mM} \mathrm{NaCl}$, were analyzed for released GlcNAc.

Enzyme activity in samples from primary amniotic fluid cell cultures was studied for the effect of repeated freezing in liquid nitrogen, repeated sonication, heat inactivation at 55 and $70^{\circ} \mathrm{C}$,

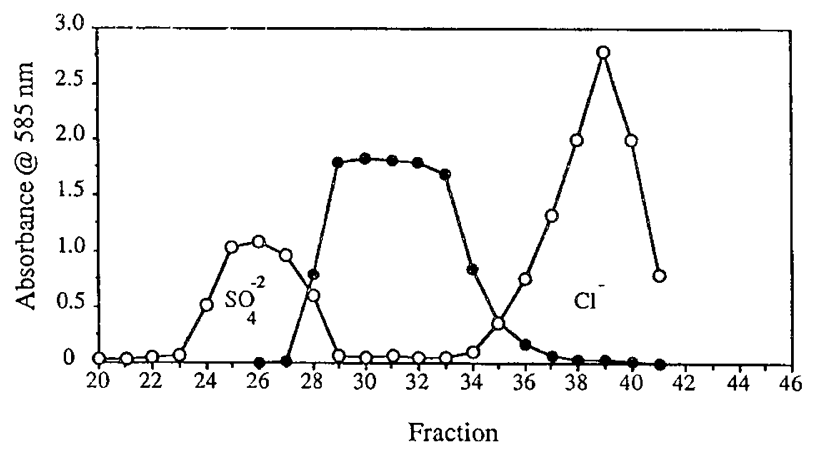

Fig. 1. Sephadex G-10 chromatography $(2 \times 125 \mathrm{~cm})$ for desalting GlcNAc(6S) prepared by direct sulfation. Absorbance $(\bullet)$ determined by the modified method of Reissig as described in "Methods and Materials." Conductivity $(\mathrm{O})$ reduced to scale. and inhibition by $\mathrm{Na}_{2} \mathrm{SO}_{4}$ and $\mathrm{NaCl}$. The $\mathrm{Km}$ and $\mathrm{V}_{\max }$ were determined by the method of Wilkinson (17).

\section{RESULTS}

Reissig method. The absorbance maximum for GlcNAc in $500 \mu \mathrm{L} \mathrm{H} \mathrm{H}_{2} \mathrm{O}$ occurred at $585 \mathrm{~nm}$ and the absorbance for a $10 \mu \mathrm{g}$ sample decreased by only $2.0 \%$ over a 25 -min period. Absorbance with increasing concentrations of GlcNAc was linear from 0 to $0.2 \mathrm{mM}$ and maximum absorbance occurred with the potassium tetraborate solution at $\mathrm{pH}$ 9.5.

Substrate preparation and characterization. Sephadex G-10 chromatography effectively removed free $\mathrm{SO}_{4}{ }^{-2}$ and $\mathrm{Cl}^{-}$(Fig. 1) after direct sulfation by chlorosulfonic acid. The sulfated monosaccharide, in spite of its larger molecular size, eluted later than free $\mathrm{SO}_{4}{ }^{-2}$ which could be attributed to ionic interaction or possibly adsorption to the gel. The GlcNAc(6S) prepared by direct sulfation and the commercial preparation co-migrated on thin-layer chromatography in both solvent systems, co-eluted from Sephadex G-10, coeluted from Dowex AG 1-X8 with 0.2 $\mathrm{M} \mathrm{NaCl}$ and the NMR spectra were identical (data not shown).

Enzyme assay. The pH optimum for GlcNAc 6-sulfatase from skin fibroblasts and primary cultures of amniotic fluid cells was 5.5 (Fig. 2). The formation of GlcNAc with increasing protein concentration was essentially linear to at least 0.1 absorbance units for skin fibroblasts and at least 0.05 absorbance units for amniotic fluid cells. The formation of GlcNAc with time was linear for at least $24 \mathrm{~h}$ for both tissue sources.

The specific activities for GlcNAc 6-sulfatase from both cultured skin fibroblasts and primary cultures of amniotic fluid cells were not normally distributed but after a $\log _{e}$ transformation (Fig. 3), a normal distribution could not be rejected statistically by the Shapiro-Wilk test (18). The specific activities for these normal controls are summarized in Table 2 . The sp act of GlcNAc 6-sulfatase in cultured skin fibroblasts from normal controls, patients with Sanfilippo syndrome, type D and MPS patients with other sulfatase deficiencies are shown in Table 3. Activities of the three known MPS IIID skin fibroblast cell lines were more than $4 \mathrm{SD}$ below the normal control mean for fibroblasts and more than 5 SD below the control mean for amniotic fluid cells (log-transformed data). Activities of the three known MPS IIID skin fibroblast cell lines, based on the untransformed data, were $2.6,0$, and $7.8 \%$ of the normal control mean and these values compared favorably with those reported for specific activities of MPS IIID patients using other assay procedures (Table 1).

Enzyme properties in amniotic fluid cells. The $\mathrm{Km}$ and $\mathrm{V}_{\max }$ for GlcNAc 6-sulfatase from primary cultures of amniotic fluid cells, were $24.0 \mathrm{mM}$ and $20.7 \mu \mathrm{g}$ GlcNAc released $/ \mathrm{h} / \mathrm{mg}$ protein respectively. At $55^{\circ} \mathrm{C}$, sp act was reduced $35 \%$ during the first 60 min after which enzyme activity was relatively stable up to 120 $\min$. At $70^{\circ} \mathrm{C}$, however, specific activity was reduced by 70 and

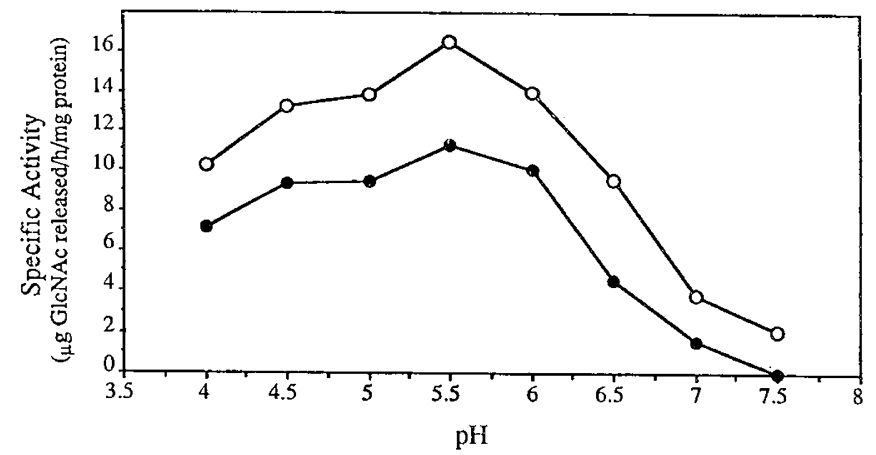

Fig. 2. Effect of $\mathrm{pH}$ on the activity of $\mathrm{N}$-acetylglucosamine 6-sulfate sulfatase. Enzyme sources were cultured skin fibroblasts from a normal control ( ) and a composite of 25 primary cultures of amniotic fluid cells $(O)$. 

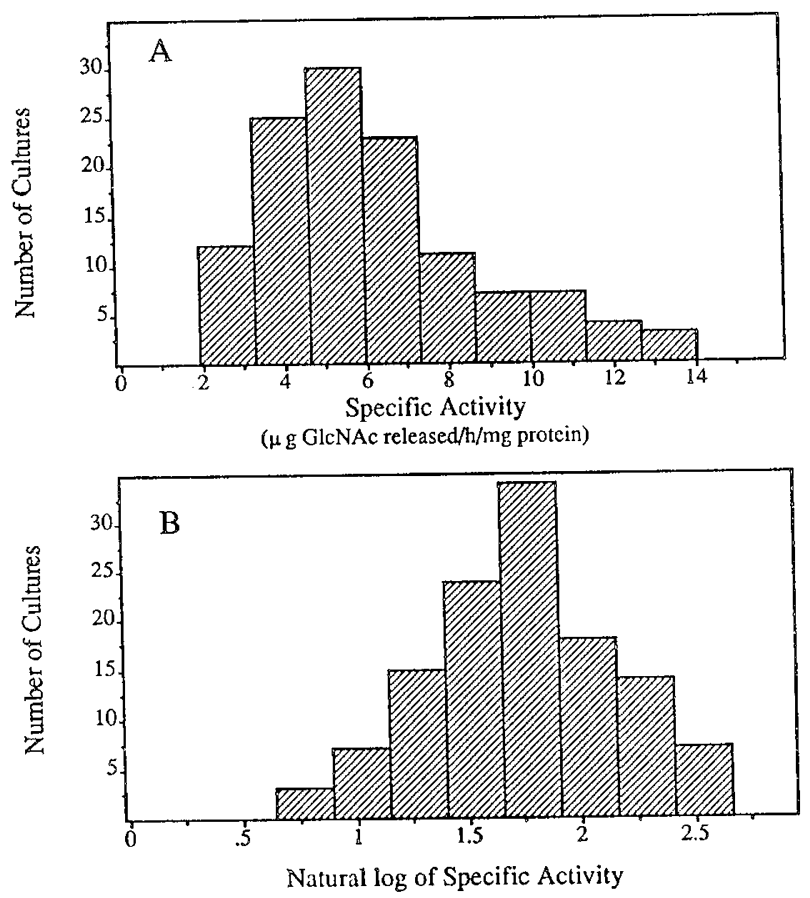

Fig. 3. Frequency distribution of specific activities $(A)$ and their logtransformed values $(B)$ for $\mathrm{N}$-acetylglucosamine 6-sulfate sulfatase from 122 primary cultures of amniotic fluid cells.

Table 2. Sp act and their natural log-transformed values for $\mathrm{N}$ acetylglucosamine 6-sulfate sulfatase in cultured skin fibroblasts from normal controls and primary cultures of normal amniotic

\begin{tabular}{|c|c|c|c|c|}
\hline & \multicolumn{2}{|c|}{$\begin{array}{l}\text { Skin fibroblasts } \\
\quad(n=11)\end{array}$} & \multicolumn{2}{|c|}{$\begin{array}{c}\text { Amniotic fluid } \\
\text { cells } \\
(n=122)\end{array}$} \\
\hline & Sp act* & $\ln$ & Sp act* & $\ln$ \\
\hline Mean & 7.7 & 1.9 & 6.2 & 1.7 \\
\hline $\mathrm{SD}$ & 4.1 & 0.5 & 2.6 & 0.4 \\
\hline Minimum & 3.8 & 1.3 & 1.9 & 0.6 \\
\hline Maximum & 17.0 & 2.8 & 13.0 & 2.6 \\
\hline $\begin{array}{l}\text { Coefficient of vari- } \\
\text { ation }\end{array}$ & 41.7 & 23.9 & 53.8 & 24.2 \\
\hline
\end{tabular}

$*_{\mu \mathrm{g}}$ GlcNAc released $/ \mathrm{h} / \mathrm{mg}$ protein.

Table 3. $N$-acetylglucosamine 6-sulfate sulfatase activity in cultured skin fibroblasts from normals, patients with MPS IIID, and patients with other sulfatase deficiencies

\begin{tabular}{llcc}
\hline \multicolumn{1}{c}{ Cell line } & Sp act* & ln \\
\hline Normals $(n=11)$ & & $7.7 \pm 4.1$ & $1.9 \pm 0.5$ \\
& & & \\
Sanfilippo D & GM 5093 & 0.2 & -1.6 \\
Sanfilippo D & WG 1004 & 0.0 & \\
Sanfilippo D & MGE-SFD & 0.6 & -0.5 \\
& & & \\
Multiple sulfatase & GM 4681 & 0.0 & \\
Multiple sulfatase & GM 3245 & 0.6 & -0.5 \\
Multiple sulfatase & MGE-MSD & 0.3 & -1.2 \\
Hunter & GM 0615 & 3.0 & 1.1 \\
Maroteaux-Lamy & GM 2849 & 4.1 & 1.4 \\
Sanfilippo A & GM 1881 & 4.8 & 1.6 \\
\hline
\end{tabular}

* The specific activity ( $\mu \mathrm{g}$ GIcNAc released/h/mg protein) for the 11 normal controls is the group mean $\pm \mathrm{SD}$. The specific activities for the cell lines from MPS patients is the result of a single determination in the same experiment.
$100 \%$ after 30 and 90 min, respectively. Repeated freezing, up to five times, had little effect on enzyme activity with only a $16 \%$ decrease after the first three freeze cycles. Sonication for 45 $s$ in 5-s intervals did not affect enzyme activity adversely. Sodium sulfate was highly inhibitory to GlcNAc 6-sulfatase activity causing $95 \%$ inhibition and $100 \%$ inhibition when present in 10 and $30 \mathrm{mM}$ concentrations, respectively. Sodium chloride was considerably less inhibitory. The sp act in a normal control with 8.0 $\mathrm{mM} \mathrm{NaCl}$ (due to the $\mathrm{NaCl}$ present in the enzyme preparation) was reduced only 13 and $28 \%$ when the total $\mathrm{NaCl}$ concentration in the incubation mixture was raised to 40 and $160 \mathrm{mM}$, respectively.

\section{DISCUSSION}

Cell lines from patients with MPS IIID, were clearly distinguished from normal controls by the procedure presented. Cell lines from patients with multiple sulfatase deficiency were also deficient in GlcNAc 6-sulfatase activity and the differential diagnosis would require assays of additional sulfatases. The assay is effective, relatively rapid, and simple to perform. The sulfated monosaccharide substrate is easier to prepare than oligosaccharide substrates and is also available commercially. The use of a spectrophotometric procedure obviates the need to work with radioactive materials.

GlcNAc 6-sulfatase from primary cultures of amniotic fluid cells was found to be a relatively stable enzyme with respect to heat inactivation, repeated freezing and repeated sonication. This is advantageous for enzyme isolation and sample preparation, which necessitate such potentially damaging procedures. Basner et al. (9) found greater heat sensitivity for GlcNAc 6-sulfatase from human urine, with more than $90 \%$ of enzyme activity toward a trisaccharide substrate destroyed after only $3 \mathrm{~min}$ at $70^{\circ} \mathrm{C}$. Inhibition by $\mathrm{Na}_{2} \mathrm{SO}_{4}$ was potent and similar in magnitude to that found by Basner et al. (9) who reported that a $17-\mathrm{mM}$ concentration gave $\geq 95 \%$ inhibition. This emphasizes the importance of using a substrate preparation free of $\mathrm{SO}_{4}{ }^{-2}$. The effect of $\mathrm{NaCl}$ was less than that suggested by Kresse et al. (8) who recommended that cell pellets not be homogenized in $0.15 \mathrm{M}$ $\mathrm{NaCl}$ because this concentration was considered highly inhibitory toward GlcNAc 6-sulfatase activity. The primary cultures of amniotic fluid cells used in this study were prepared in $0.15 \mathrm{M}$ $\mathrm{NaCl}$ although the concentration in the recommended incubation mixture was substantially less.

The deficiency of GlcNAc 6-sulfatase activity found in multiple sulfatase deficient cell lines was not consistent with the findings of Yutaka et al. (19). They used a disaccharide substrate and made multiple determinations of the sp act of GlcNAc 6sulfatase in several cultures from a single multiple sulfatase deficient fibroblast cell line. The activity they reported was usually normal but in some samples a reduction of between $30-$ $50 \%$ of the control values was found. They proposed that the normal activity levels might have resulted from the fact that cells were cultured in medium that was maintained at a $\mathrm{pH}$ of 7.4 and similar results were obtained by Fluharty et al. (20) who reported a rise in arylsulfatase A (EC 3.1.6.1) activity when multiple sulfatase-deficient cell lines were maintained at that same $\mathrm{pH}$. The cell lines in the present study were maintained in a $\mathrm{CO}_{2}-\mathrm{HCO}_{3}^{-}$buffered medium which creates a lower $\mathrm{pH}$.

Many biologic functions fail to follow a truly normal distribution and the transformed data are often shown to follow a log-normal distribution $(21,22)$; for example, a log-normal distribution was also found by Vance et al. (23) for N-acetyl$\alpha$-D-glucosaminidase (EC 3.2.1.50), another heparan sulfate-degrading enzyme, the deficiency of which results in Sanfilippo syndrome, type $\mathrm{B}$. The enzyme sources for their study were serum and plasma.

There has been no report of prenatal diagnosis for MPS IIID but it would be feasible using this spectrophotometric assay if it is assumed that an affected fetus would have activity levels of 
the same magnitude as found in the affected patients. The validity of this assumption will, of course, await the study of at-risk pregnancies.

\section{REFERENCES}

1. McKusick VA, Neufeld EF 1983 The mucopolysaccharide storage diseases. In: Stanbury JB, Wyngaarden JB, Frederickson DS, Goldstein JL, Brown MS (eds) The Metabolic Basis of Inherited Disease, 5th ed. McGraw-Hill Book Company, New York, pp 751-777

2. Haust MD, Gordon BA 1986 Ultrastructural and biochemical aspects of the Sanfilippo syndrome,-type III genetic mucopolysaccharidosis. Connect Tissue Res 15:57-64

3. Kresse H, Paschke E, von Figura K, Gilberg W, Fuchs W 1980 Sanfilippo disease type $\mathrm{D}$ : Deficiency of $\mathrm{N}$-acetylglucosamine 6-sulfate sulfatase re quired for heparan sulfate degradation. Proc Natl Acad Sci USA 77:68226826

4. Gatti R, Borrone C, Durand P, De Virgilis S, Sanna G, Cao A, von Figura K, Kresse H, Paschke E 1982 Sanfilippo type D disease: Clinical findings in two patients with a new variant of mucopolysaccharidosis III. Eur $J$ Pediatr 138:168-171

5. Coppa GV, Giorgi PL, Felici L, Gabrielli O, Donti E, Bernasconi S, Kresse H, Paschke E, Mastropaolo C 1983 Clinical heterogeneity in Sanfilippo disease (mucopolysaccharidosis III) type D: presentation of two new cases. Eur $\mathbf{J}$ Pediatr 140:130-133

6. Kaplan P, Wolfe LS 1987 Sanfilippo syndrome type D. J Pediatr 110:267-271

7. Boustany R-M N, Oppenheimer E, Johns DR, Horwitz AL, Kolodny EH 1988 Poster presentation at the First International Congress on Mucopolysaccharidosis and Related Diseases, Minneapolis, Minnesota, May 20-22

8. Kresse H, von Figura K, Klein U, Glössl J, Paschke E, Pohlmann R 1982 Enzymic diagnosis of the genetic mucopolysaccharide storage disorders. Methods Enzymol 83:559-572

9. Basner R, Kresse H, von Figura K $1979 \mathrm{~N}$-acetylglucosamine 6-sulfate sulfatase from human urine. J. Biol Chem 254:1151-1158

10. Elliott H, Hopwood JJ 1984 Detection of the Sanfilippo D syndrome by the use of a radiolabeled monosaccharide sulfate as the substrate for the estimation of $\mathrm{N}$-acetylglucosamine 6-sulfate sulfatase. Anal Biochem. 138:205 209

11. Freeman C, Hopwood JJ 1987 Human liver N-acetylglucosamine-6-sulphate sulphatase. Biochem J 246:355-365

12. Robertson DA, Callen DF, Baker EG, Morris CP, Hopwood JJ 1988 Chromosomal localization of the gene for human glucosamine-6-sulphatase to 12q14. Hum Genet 79:175-178

13. Nowakowski RW, Thompson JN, Taylor KB 1988 A spectrophotometric assa for Sanfilippo D syndrome with prenatal diagnostic potential. Am J Hum Genet 43 (suppl 3):A242

14. Reissig JL, Strominger JL, Leloir LF 1955 A modified colorimetric method for the estimation of N-acetylamino sugars. J Biol Chem 217:959-966

15. Lloyd AG 1962 Fractionation of the products of the direct sulphation of monosaccharides on anion-exchange resin. Biochem $J$ 83:455-460

16. Ishihara K, Sobue M, Uemura D, Tsuji M, Nakanishi Y, Suzuki S 1976 Nacetylgalactosamine 4,6-bissulfate in rat urine: isolation, identification and chemical synthesis. Biochim. Biophys Acta 437:416-430

17. Wilkinson GN 1961 Statistical estimations in enzyme kinetics. Biochem J 80:324-332

18. Shapiro SS, Wilk MB 1965 An analysis of variance test for normality (complete samples). Biometrika 52:591-611

19. Yutaka T, Okada S, Kato T, Inui K, Yabuuchi H 1981 Properties of sulfatases in cultured skin fibroblasts on multiple sulfatase deficient patients. Clin Genet 20:296-303

20. Fluharty AL, Stevens RL, Davis LL, Shapiro LJ, Kihara H 1978 Presence of arylsulfatase A (ARS A) in multiple sulfatase deficiency disorder fibroblasts. Am J Hum Genet 30:249-255

21. Elveback LR, Guillier CL, Keating, FR Jr 1970 Health, normality, and the ghost of Gauss. JAMA 211:69-75

22. Flynn FV, Piper KAJ, Garcia-Webb P, McPherson K, Healy MJR 1974 The frequency distributions of commonly determined blood constituents in healthy blood donors. Clin Chim Acta 52:163-171

23. Vance JM, Pericak-Vance MA, Elston RC, Conneally PM, Namboodiri KK Wappner RS, Yu PL 1980 Evidence of genetic variation for $\alpha$-N-acetyl-Dglucosaminidase in Black and White populations: a new polymorphism. Am J Med Genet 7:131-140 